\title{
Effectiveness of Teaching English Subject using Drama on the Development of Students' Creative Thinking
}

\author{
Dr. BashayerRaghianAlbalawi \\ Assistant Professor of TEFL, Curriculum and Instruction Department Faculty of Arts \& Education \\ Tabuk University
}

\begin{abstract}
The present study investigates the influenceof teaching English subject using drama on the development of intermediate students' creative thinking. The sample population of the study comprises two randomly selected first year intermediate classes of the 33 intermediate female school in Tabuk. One class of 24 students has been assigned to be control group. The other class of 23 students has been assigned to be experimental. Upon review of related literature and previous studies, 4 dramatic teaching scenes were prepared in the light of drama for each lesson in unit 10 (the body) of first year intermediate English subject. Tool (Torrance creative thinking test) was adopted upon review of literature and related studies. Validity and reliability of the tools have been measured. Applying the pre-test of creative thinking for both control and experimental groups. The control group has been taught using the traditional way of teaching whereas the experimental group has been taught using drama.The post--test of creative thinking applied by the end of teaching the assigned unit.Data was statistically analyzed.Results have been discussed.Based on results recommendations and suggestions have been occurred.
\end{abstract}

\section{Introduction}

Tell me and I forget. Teach me and I remember. Involve me and I learn (Benjamin Franklin).

Students' involvement in the learning process has become the main aim of modern approaches that focus on student-centered class rather than teacher-centered class. Clever involvement that demands a student to use creative thinking skills is the kind of involvement that helps student to learn effectively. Many methods has been used to assess students' effective involvement. Drama is one of the most important methods that provide much more involvement for both teachers and students in the learning process.

In foreign language classroom, drama is an effective method as Mattevi (2005) states "the use of drama in the language classroom allows the teacher to present the target language in an active, communicative and contextualized way. Dramatization helps the teacher address the four skills of language learning (speaking, listening, writing and reading), and it also favors and facilitates the study of some often neglected aspects of language such as pronunciation and body language."

Blanch (1974) also points out "the two elements of drama are action and dialogue, and both have a place in the foreign-language learning experience. They may be introduced into the classroom by means of a "drama lab," a learning activity that permits students to act out foreign language materials such as tableaus, poetry, ballads, folklore, and plays. Drama allows the student to express his individuality, and the material, if it is culture-related, brings to life the cultural context of the foreign language." Campbell (2008) study proved the effectiveness of using drama on students' achievement whereas the effect of drama in foreign language teaching and learning has been the aim of many researches such as Barreto (2014), Gomez (2010),Baraldi (2009), Uddin (2009),Ntelioglou (2006), Culham (2003) and Gaudart (1990).

Drama also approved its effectiveness on developing creative thinking. Özdemir andÇakmak (2008) states "Drama enables students, in all levels of education, develop their intellectual skills such as creativity, problem solving, communication, socialization and empathy and it gives individuals the opportunity for selfactualization, group work and sharing their responsibilities."Many studies revealed the effect of drama on creativity such the study of Ortiz-Seda (1984),Dupre (2006)and Taskin (2013).

Using of drama in foreign language class has many advantages. Cunico (2005) states that "drama is an under-exploited resource in the foreign language classroom for promoting intercultural competence and developing an awareness of the interpersonal dimension embedded in the language we use. Drama also offers ample opportunities to explore nuances of the foreign culture as well as conflict situations and emotions which are seldom encountered in textbook dialogues and material, thus opening up to the students a world which is often denied to them in the foreign language classroom".

Emphasizing this Gasparro and Falletta (1994) point out "The use of poetry as drama in the English as a Second Language (ESL) classroom enables students to explore the linguistic and conceptual aspects of the written text without concentrating on the mechanics of language. Students are able to develop a sense of 
awareness of self in the target culture through dramatic interpretations of the poems. Teachers using this technique need to consider poetry that matches their students' language skills, ages, and interests."

Even (2008) adds that through drama, "Students enter imaginary worlds that they cooperatively construct, experience, furnish, arrange, and change.Thus, drama situations can liberate and at the same time deeply stimulate and challenge learners' take on communicative situations, grammar, and literary texts"

The effect of drama also extend to the affective skills of the students.Özdemir andÇakmak (2008) points out "a number of studies of the effects of drama on individuals' cognitive and affective characteristics have been carried out recently. These studies revealed that drama had positive impact on students' development of communication skills, socialization levels, development of emotional intelligence, social skills, empathic skills and empathic tendencies regardless of the grade levels of the students".

Kao, etal. (2011) also stressed, "In drama-oriented English as foreign language (EFL) classrooms, teachers often ask questions to shape the story, unveil the details, sequence the scenes, create a beneficial linguistic environment to elicit student output and promote meaning negotiation in the target language."

Therefore, "for more than 30 years drama has been promoted as a valuable teaching tool for language learning. Recent research results have reinforced this position." ( Dunn\& Stinson, 2011).

Culham (2003) observed benefits from using simple drama activities with students and in teacher-in-service workshops as follows:

1. Students are able to express themselves in ways other than through words.

2. Drama activities offer community-building opportunities in a classroom where there are students of varying levels of language proficiency

3. Teachers are also able to use non-verbal cues to demonstrate caring and concern for students in a way that more formal language instruction does not allow, bound as it is by the physical constraints and the pressure to understand.

4. Non-verbal drama activities provide an excellent means of releasing the stress of language learning.

5. Students, often hesitant to speak out, can become confident when the language expectation is removed entirely.

6. "Total Physical Response is enhanced through drama activities.

7. In all drama work, power dynamics shift as the teacher becomes a participant alongside the students.

8. Non-verbal drama activities transfer directly to verbal ones, and subsequent verbal interchanges are triggered by these non-verbal activities.

On the other hand, Burke and O'Sullivan (2002: xx) identified seven reasons to incorporate drama in the second language classroom:

1. Teachers and students can concentrate on pronunciation.

2. Students are motivated.

3. Students are relaxed.

4. Students use language for real purposes.

5. Risk-taking equals heightened language retention

6. Community is created.

7. Students and teachers can approach sensitive topics

Emphasizing the importance of drama in language teaching, Kao and O'Neill (1998: 4) state in their book, Words into Worlds: "Drama does things with words. It introduces language as an essential and authentic method of communication. Drama sustains interactions between students with the target language, creating a world of social roles and relations in which the learner is an active participant. Drama focuses on the negotiation of meaning (Snyman\& De Kock, 1991). The language that arises is fluent, purposeful and generative because it is embedded in context. By helping to build the drama context, they develop their social and linguistic competence as well as listening and speaking skills."

However, drama is used in the present research to represent the educational drama used for learning not drama as an atr( i.e) the use of drama as method, as a means of learning other subjects. According to Taylor (2008) "Narrowing the term in that way paves the way for a conceptual move which set up 'drama as learning' in opposition to 'drama as an art form' (when drama is taught as a separate subject discipline) without further exploration. This was not the way the term was used by advocates of Drama in Education who saw in the formulation 'drama for learning' a way of embodying the change of attitude or understanding which came about as a result of participation in the drama and which transcended mere developmental objectives or acquisition ofpersonal qualities."Furthermore, previous studies are to confirm the importance of drama in both language teaching and creative thinking.

More recently,Barreto (2014) studied language acquisition through the use of educational drama is explored. Research has demonstrated that using drama in the classroom can help language development of all 
students in order to achieve English proficiency. Engaging in a learning experience through drama activities without stress increases motivation for participation in the classroom, especially for English language learners. The drama experience is made more meaningful by emphasizing a purpose, which requires problem-solving skills, along with various modes of language use. Moreover, evidence of language development can be assessed through various modes. Within the context of drama, speaking and listening skills are fostered in peer-peer, group, and student-teacher interactions, which are beneficial for reading and writing. In order to further explore the results and benefits of drama in the classroom, various types of drama strategies and their applications were studied.

Taskin (2013) investigated the effect of creative drama-based instruction on fifth graders' science achievements in the light and sound unit and scientific process skills. This quasi-experimental research was conducted in one of the public elementary schools in Turkey during 2009-2010 academic year. A light and sound achievement test was developed and administered to randomly selected 60 students. The experimental group was instructed through creative drama-based implications and the control group was never exposed to creative drama. An instruction material including five lesson plans was constructed for the leader to administer creative drama-based instruction. The unit was instructed to each group for three weeks. A science achievement test and a scientific process skills test were administered to each group as pre-post test. An independent sample t-test revealed that there were significant differences in the means of creative drama applications, science achievement and scientific process skills.

Cushman (2011) documented the use of a pedagogy called dramatic inquiry (Edmiston, 2011) and active, rehearsal room approaches to reading Shakespeare (Royal Shakespeare Company Toolkit, 2010) in one third grade classroom during the 2010-2011 school year. Simultaneously, this research describes classroom events built around the skills-based models of reading instruction while it also documents the introduction of a new way of structuring reading events in the same classroom using multiple ways of knowing beyond verbal and abstract (e.g. dramatic play, somatic, kinesthetic, gestural, musical, etc.). The findings describe the key linkages between changes in reading instruction towards dramatic inquiry and the changes in ELLs access to academic literacy and expanded repertoires for meaning-making. Findings from this research extends the scholarship in ELL literacy education by showing the significance of long-term collaborative and inquiry based multimodal forms of learning. The ELL students in this classroom were highly engaged with the dramatic reading tasks precisely because such tasks were perceived by the students as challenging and created authentic reasons to re-read for deepening meaning. The dramatic inquiry was sustained over the long term because the entire ensemble of learner's (which included teachers) displayed an ongoing willingness to collaboratively face the intriguing and complex stories and rich, rhythmic and figurative language of Shakespeare. It was also significant to the long-term retention of language and conceptual understandings, that the dramatic inquiry took place in cycles of returning again and again to similar concepts, inquiry questions and language and over the long-term across four different Shakespeare plays. Lastly, it was essential to sustained the ELLs high engagement in reading comprehension strategies that the dramatic reading events not only valued the students active, embodied and playful engagements with learning, but this set of practices made highly visible long-term intertexuality and other forms of higher order thinking by the students so as to become a semiotic resource for everyone to use in the ongoing inquiry.

Gomez (2010) studied the effectiveness of the use of drama in the teaching of English as a second language (ESL) as opposed to traditional instructional methods, specifically to the enhancement of the oral skills, including pronunciation and fluency. The students assessed were Spanish mother tongue speakers and attended a public school in Madrid, Spain. Two classes from the same year group received instruction in the differing methods over a three-week period. They were examined pre and post instruction. Data was collected and analyzed using a two-tailed t-test for two independent samples with equal variance to examine whether either method was more effective. The researcher's hypothesis was that there would be no significant difference between the two methods. However, the results of the study concluded that teaching English through drama was more effective than using traditional methods. The proposed null hypothesis was rejected.

The study of Baraldi (2009)examined ways in which drama and theatre techniques and practices, as implemented in the elementary classroom and combined with pedagogical practices to teach and learn a second language, can create the appropriate conditions that promote environments conducive for content learning and to aid the English Language Learner (ELL). This research is a qualitative case study that follows one fourth-and fifth-grade combination classroom during a period of six weeks. During this time, ten drama and theatre structures were used to teach an economics unit. The twenty-seven participants, including five ELL students, were observed while participating in the drama sessions, when interacting with each other, and during exchanges with the teacher. All participants were interviewed at several stages to obtain their reactions and responses as they participated in this project. Fieldnotes, participant observation, and interviews were used to gather data. To understand what students, particularly ELL students, thought about the use of drama and theatre to help them learn academic content and English, their own words were used as direct feedback to inform the 
development and improvement of existing teaching practices. The results of this research suggest that all the participants: 1) appreciated the use of drama in the classroom; 2) learned the content of the economics unit; and, 3) would use drama in other subject areas. In particular, ELL students expressed an interest and desire to use drama and theatre techniques to learn English in the future. Similar concepts were discovered that could be used in both drama and ELL education to achieve their particular goals. The six strategies from both fields and applied to teach the drama sessions were as follows: 1) engage students in conversation; 2) encourage cooperative learning; 3) form small groups; 4) promote writing; 5) incorporate body use; and, 6) utilize students' prior knowledge. The participants' experiences suggested that combining each field's similar teaching tools can benefit both language and content learning.

The purpose of Uddin (2009) study was to explore the relationship between counseling techniques and second language vocabulary acquisition for adult second language learners. This study implemented two counseling techniques, Role play and Story telling, in teaching second language vocabulary to adult second language learners. The results of this study showed that both techniques Role playing and Story tellingwere reported to be favorable and successful by all participants who attended this study. The participants not only successfully enhanced vocabulary but also managed to utilize those words into their Role play and Story telling activities. Role play enhanced their fluency of communicative skills which necessitates vocabulary enhancement. Without such an increment of vocabulary, their progress would have been slower. Story telling assisted participants to take time to reflect on their stories and to take full use of the vocabulary acquired earlier. These techniques particularly assisted in making learners become independent learners, owning their language skills and, as a result, making them empowered. The results of the statistical analysis conducted on the participants' pre and post test scores also indicated that all participants made marked improvement, and thus both Role play and Story telling can help adult ESL learners to improve their vocabulary and communicative language skills. Therefore, it can be said that both Role play and Story telling can be successfully implemented in teaching second language vocabulary to adult second language learners. However, these techniques can only be applicable to intermediate and advanced level of second language learners.

Campbell (2008) investigated the impact ofan infused theater arts programconsisting ofdrama, social studies, and language arts on the academic achievement of

fifth grade students in 7 middle and elementary public schools in an urban school district.In addition, the researcher examined the influence ofthis infused theater arts model onthe behaviors ofstudents and teachers within the same setting. The primary measures used were language arts scale scores obtained fromthestate's standardized tests, New Jersey Assessment ofSkills and Knowledge (NJASK5),and students' first and fourth marking period grades. Students' and teachers' self-reported reflections were usedto assess behaviors. Two-way analysis ofvariance(ANOVA) was used to examine the effects ofgender, school, and socioeconomic status on students' academic achievement. Chi-square tests were used to analyze students'marking period grades, students' behaviors, and teachers' behaviors.Data revealed that the infused theater arts program did have a significant impacton students' academic achievement. The data also showed that students who participatedin the infused theater arts program for 1 year or more outperformed their peers whoparticipated with the traditional curriculum for the same period oftime. Significantdifferences were observed in students' mean scores across schools. The influence ofthe infused theater arts program on students' and teachers'behaviors were significant for some measures assessed. When teachers' responses wereanalyzed, the influence appeared to vary across schools.

Dupre (2006) study presents the results of a yearlong ethnography, conducted by a middle school teacher within her seventh grade language arts class. The research explores student response to a curriculum that integrated creative drama, playwriting, tolerance, and social justice. Students were involved in experiential learning activities, including improvisation, Forum Theatre, and playbuilding. Following activities articulated by the Contemporary Holocaust Foundation, students participated in community-building activities, created human sculptures depicting incidences of injustice, and wrote scenes exploring intolerance. Participants listened to a presentation on social justice by Southern Poverty legal activist Morris Dees and a lecture on the legal history of social segregation in America by University of New Mexico law professor, Sherri Burr. Students also read Anne Frank: The Diary of a Young Girl and attended a performance of The Laramie Project. In addition, students conducted a school-wide survey assessing labels, cliques, and popularity. These data, along with suggested action programs to reduce social segregation at school, were presented to state legislative leaders as part of Project Citizen.Reproduced with permission of the copyright owner. Further reproduction prohibited without permission. Data included 85 participant observations, nine 30- to 90-minute interviews, creative and expository student writing, journal entries, process papers, surveys, and sociograms. Findings revealed that the curriculum stimulated young adolescents to identify themselves as important to the class, the school, and theoutsideworld. They used their writing, researching, and performing skills to present critical learning to adult and peer audiences. Sociogram results indicated that students learned to select members outside of typical genderhomogenous groups. Another result of the curriculum was increased cognition of multiple viewpoints and 
personal responsibility in incidences of social injustice. Implications of the study to educators in view of No Child Left Behind and Adequate Yearly Progress were also discussed.

Ntelioglou (2006) investigated the impact of integrated drama/ESL lessons on second language learners' language skills. The dual focus of the study was to use drama to support the listening, reading, speaking and writing skills of the language learners, and to examine issues of "Immigration, Canadian Identity and Multiculturalism" through drama in an ESL/humanities first-year university course. Drama education strategies were designed to create a context for reflecting the narratives of ESL learners' own lived experiences. The ESL students negotiated between fictional and actual experiences, past and present, and made use of in-role and out of role reflection throughout. The use of both verbal and non-verbal communication, collaboration, interpretation of information, imagination and risk-taking in the safety of fiction supported students' significant engagement through drama. The research findings suggest that the integration of drama helped students cross borders of cultures, identities and literacies in the multicultural second language classroom.

Alesaoy (2004) used the dramatization of Arabic language course in order to see its effect on developing some topics of language and social skills among mentally retarded students. The main purpose of this study is to figure out the effects of using dramatization on language and social skills of retarded students. The problem: The number of mentally retarded is raising up in addition to the failure of the ordinary ways in teaching for these students. This study depended on experimental method and used 1 - dramatized unit 2language skill measurement 3- social skill measurement. Sample of ( $\mathrm{N}=36)$ mentally retarded students from the fourth year is divided into 1- control group 2- experimental group 3- sample of the Arabic book which is decided on them. The results showed that there are statiscally significant differences between the experimental group and the control group in the post test of the language skills scale in favor of experimental group. There are statiscally significant differences between the experimental group and the control group in the post test of the social skills scale in favor of the experimental group. There are statiscally significant differences between the experimental group and the control group in the seqt test of the language skills scale in favor of the experimental group. There are significant differences statically between the experimental group and the control group in the seqt test of the social skills scale in favor of experimental group. There are statiscally significant differences between the experimental group and the control group in the reliability test of the language skills scale in favor of the experimental group. There are statiscally significant differences between the experimental group and the control group in the reliability test of the social skills scale in favor of the experimental group.

Culham (2003) investigated the potential of drama as a conduit for language acquisition and intercultural exchange. Drawing from practice, this thesis identifies both obstacles and opportunities encountered when drama is introduced to ESL adults students. Interactive drama activities and student reactions are detailed in this study, with a focus on the paralinguistic features that drama provides participants. Established Drama in Education activities have been modified to suit the needs of ESL learners, and those adjustments and findings are detailed. The findings of this research suggest that ESL teachers can, through drama, access their students in significant ways and, in the process, promote language proficiency and encourage intercultural discovery. Espoused theory evidenced by interviews and personal observations is supported by research in the fields of Drama in Education and Second Language Education; extracts from ESL student journals are also included. The findings of this study can be applied to language learners of all ages and levels, but this study has primarily involved adult ESL learners at the lower levels.

Gaudart (1990) study investigated the use of drama activities in English-as-a-Second-Language (ESL) instruction in Malaysia. Instruction occurred over an extended period of time and involved over 300 teachers, with a wide range of training and experience, in secondary and higher education institutions. Students were lowlevel, intermediate, or advanced learners in rural, urban, or tertiary schools. Class size ranged from 10 to 51 students. Types of drama activities used were language games (including improvisation), pantomime, role playing, and simulations. They emphasized listening and speaking skills. In general, it was found that drama techniques worked for most teachers and that some techniques worked better in certain circumstances than in others. Activities that do not emphasize performance were found more universally applicable than those that do. Some variability was found in the success of different activity types with different ability and school groups. It is concluded that drama activities are useful in motivating students, holding their attention, and stimulating their creativity. However, student proficiency, needs, attitudes, experience, abilities, age, and interests must be considered. Some teachers find integrating drama activities to be difficult; convincing and training teachers in their use is essential to success.

Ortiz-Seda (1984) investigated the use of creative dramatics in the teaching of drama with Special Application to the Teaching of English as a Second Language. Since performance is the main difference between drama and fiction, it should be included in drama instruction in order to give students a complete view of what drama really is. Accordingly, a series of theatrical techniques to teach four elements of drama--plot, character, setting, and mood--were elaborated. Improvisations, pantomimes, extrapolation or expanding a 
character, and role playing are included among the activities, on the premise that the use of performance techniques should be incorporated with the standard methods of literary analysis and taught simultaneously to help students better comprehend plays. This theory is illustrated with exercises used to teach two plays, William Shakespeare's "The Tragedy of Romeo and Juliet," and Thornton Wilder's "The Matchmaker." These plays were chosen because they presented concrete characters and situations that the students could recognize as real. In addition, genre, historical period, technical devices, and audience were considered in making the choices. These suggestions and exercises are well suited to ordinary high school students and/or freshman college students who are learning English as a Second Language (ESL). Guidelines for teachers who would like to use the activities in their classrooms are included.

\section{Context of the problem}

\section{The Study}

Recently, focus on thinking skills has become the aim of many educational systems. Some countries like USA, Venezuela and Canada teach thinking as an isolated subject. Either being taught as an isolated subject or embedded in curriculum with other subjects, teaching thinking skills has become very essential in modern education. Since we are in creativity age and language learning is a precious opportunity to develop creative thinking as language learning class is full of different life like situations and full of characters and dialogue, teaching foreign language using drama can be effective in developing students' creative thinking. Thus, the present study will investigate the effectiveness of teaching English subject using drama on the development of intermediate students' creative thinking.

\section{Statement of the Problem}

The problem of the study can be stated in the main question:what is the effectiveness of teaching English subject using drama on the development of intermediate students' creative thinking?

\section{Questions of the study}

The present research seeks to answer the following main question:

What is the effectiveness of teaching English subject using drama on the development of intermediate students' creative thinking?

The following sub-questions are derived from the main question:

1- What is the effectiveness of teaching English subject using drama on the development of first year intermediate female students' creative thinking?

2- Is there any statistically significant difference between the achievement of control group (those who study using the traditional method of teaching) and the achievement of experimental group (those who study using drama) according to the pre-creative thinking test?

3- Is there any statistically significant difference between the achievement of control group (those who study using the traditional method of teaching) and the achievement of experimental group (those who study using drama) according to the post-creative thinking test?

\section{Objectives of the study}

The present study aims at:

1- Investigating the effectiveness of teaching English subject using drama on the development of intermediate students' creative thinking.

2- Investigating relationship between students' achievment of control group (those who study using the traditional method of teaching) and the achievement of experimental group (those who study using drama) according to the pre-creative thinking test.

3- Investigating relationship between students' achievment of control group (those who study using the traditional method of teaching) and the achievement of experimental group (those who study using drama) according to the post-creative thinking test.

\section{Hypotheses}

1- Teaching English subject using drama is effective in developing first year intermediate female students' creative thinking.

2- There is a statistically significant difference at the level ( $0,05>)$ between the achievement of control group (those who study using the traditional method of teaching) and the achievement of experimental group (those who study using drama) according to the pre-creative thinking test.

3- There is a statistically significant difference at the level $(0,05>)$ between the achievement of control group (those who study using the traditional method of teaching) and the achievement of experimental group (those who study using drama) according to the post-creative thinking test. 


\section{Significance of the Study}

The importance of the present study may lies in:

1- It draws the attention toward the effectiveness of using drama in developing students' creative thinking.

2- It may provide teachers with applicable teaching situations using drama.

3- It may provide results which may be applicable in other subjects

\section{Sample of the Study}

The sample population of the study comprised two randomly selected first year intermediate classes of the 33 intermediate female school in Tabuk. One class is assigned to be control group. It comprises of 24 students. The other class is assigned to be experimental. It comprises of 23 students.

\section{Delimitations of the Study}

The present study is delimited to:

1. Academic delimitations: Investigating the effectiveness of teaching unit 10 (the body) using drama on first year intermediate female students' creative thinking. The unit comprises 4 lessons.

2. Place: 2 first year intermediate female students' classes of the 33 school in Tabuk.

3. Time: second term of the academic year 2014 - the unit has been taught over 2 weeks -4 periods per a week. 45 minutes to each period (total 8 periods $=6$ hours $=360$ minutes).

\section{Design of the Study}

The present study utilizedthe quazi- experimental method to investigate the effectiveness of teachingEnglish subject using drama for first year intermediate female students on their creative thinking.

\section{Tools of the Study}

For the purpose of the study, the following tools are used:

- Torrance creative thinking test (Arabic version is used in order to be understood by the students). The test involved simple subtests of divergent thinking and the present study uses the verbal tasks using verbal stimuli subtest. The students' answers will be scored in three scales: fluency (the total number of interpretable, meaningful, and relevant ideas generated in response to the stimulus), flexibility (the number of different categories of relevant responses), and originality (the statistical rarity of the responses).

- Four dramatic scenes for each lesson of unit 10 (the body) of first year intermediate English subject. Each dramatic scene comprised objectives; context, characters, dialogue, Peer work and group work are stressed.

\section{Procedures of the Study}

The study adopted the following procedures:

1. Review of related literature and previous studies.

2. Four dramatic teaching scenes were prepared in the light of drama for each lesson in unit 10 (the body) of first year intermediate English subject.

3. Tool (Torrance creative thinking test) is adopted upon review of literature and related studies.

4. Validity and reliability of the tools have been measured.

5. Assigning sample of the study and apply the pre-test of creative thinking for both control and experimental groups.

6. The control group was taught using the traditional way of teaching whereas the experimental group was taught using drama.

7. The post--test of creative thinking was applied by the end of teaching the assigned unit.

8. Data was statistically analyzed.

9. Results have been discussed.

10. Based on results recommendations and suggestions have been occurred.

\section{Definition of Terms}

- Drama:

Holden (1981) defined drama as any activity which asks the student to portray self or another person in an imaginary situation. In Ntelioglou(2006) "drama can be defined as Teaming by doing'. For Shand (2008) "educational drama and Second Language Instruction educational drama refers to using creative drama techniques to teach other subjects. These techniques include, but are not limited to pantomime, storytelling, story dramatization, role-playing, improvisation, theatre games, process drama, and play production." 
For the purpose of the present study, drama refers to the dramatic scenes prepared by the researcher and applied in the classroom. Each scene has a location, characters and dramatic activities that done in pairs and groups. Role-play, dialogue, simulation, games, plays, mantle expert and other activities were included.

\section{- Creative thinking :}

Taylor (2008) states " Creativity/Creative Thinking will be operationally defined Standard Composite Scores: Fluency, Originality, Elaboration, Abstractness of Titles, and Resistance to Premature Closure, along with 13 criterion-referenced measures of creative strengths: Emotional Expressiveness, Storytelling Articulateness, Movement/Action, Expressiveness of Titles, Synthesis of Incomplete Figures, Synthesis of Incomplete Lines, Unusual Visualization, Internal Visualization, Extending/Breaking Boundaries, Humor, Richness of Imagery, Colorfulness of Imagery, and Fantasy.

Torrance (1969), a pioneer in creativity research, further defined creativity as sensing problems, searching for possible solutions, drawing hypotheses, testing, evaluating, and communicating results to others. Moreover, Torrance described the creative process as including original ideas, different points of view, breaking out of the mold, recombining ideas, and seeing new relationships among components as different ways creativity can be assessed.

In the present study, creative thinking refers to students' scores in Torrance test for creative thinking related to the three main skills of fluency, creativity and originality.

\section{The first question:}

\section{Data Analysis:}

To answer the first question, "What is the effectiveness of teaching English subject using drama on the development of first year intermediate students' creative thinking?", data was treated by the statistical program "SPSS" using t-test. Data treatment reveals that there is a statistically significant difference in mean scores of the pre and post test of the experimental group, the mean and Standard Deviation of pre and post grades of the experimental group is as follows:

Table(1)

\begin{tabular}{|l|l|l|l|}
\hline & N & Mean & Std. Deviation \\
\hline Pre & 22 & 52.36 & 17.82 \\
\hline Post & 22 & 102.86 & 22.73 \\
\hline
\end{tabular}

Table (1) indicated that the mean of post grades of experimental group is more than the mean of pre grades of experimental group. Paired samples T-test was usedas in the following table:

Table (2)

\begin{tabular}{|l|l|l|l|l|}
\hline experimental group & $\mathrm{T}$ & $\mathrm{df}$ & Mean Difference & $\begin{array}{l}\text { Sig. } \\
\text { p-value }\end{array}$ \\
\hline Pre-post & 12.06 & 21 & 50.50 & 0.00 \\
\hline
\end{tabular}

Table (2) indicated that there exist statistically significant differences instudents' pre and post grades of experimental group because of the p-value is less than 0.05 .

\section{The second question:}

To answer the Second question "Is there any statistically significant difference between the achievement of control group (those who study using the traditional method of teaching) and the achievement of experimental group (those who study using drama) according to the pre-creative thinking test? ", data of the pre testwas treated by the statistical program "SPSS" using t-test. Data treatmentreveals that there is no statistically significant difference in the mean grades of control and experimental groups as the mean scores of experimental group was 54.40 and the mean scores of the mean scores of the experimental group was 52.36. Std. Deviation of pre-test of control and experimental groups is as follows:

\begin{tabular}{|c|c|c|c|}
\hline \multicolumn{4}{|c|}{ Table(3) } \\
\hline Groups & $\mathrm{N}$ & Mean & Std. Deviation \\
\hline Control & 20 & 54.40 & 22.20 \\
\hline Experimental & 22 & 52.36 & 17.83 \\
\hline
\end{tabular}

Table (3) indicated that the mean of degrees of control group is more than the mean of degrees of experimental group.

To test the statistically significant difference between the creative thinking of control group (those who study using the traditional method of teaching) and the creative thinking of experimental group (those who study using drama) according to the pre-creative thinking test, independent samples $\mathrm{T}$ test was usedas in the following table: 
Table (4)

\begin{tabular}{|c|c|c|c|c|}
\hline Pre test & $\mathrm{T}$ & df & Mean Difference & $\begin{array}{r}\text { Sig. } \\
\text { p-value }\end{array}$ \\
\hline experimental $\times$ control & 0.33 & 40 & 2.04 & 0.74 \\
\hline
\end{tabular}

Table (4) indicated that there are no statistically significant differences between the creative thinking of control group (those who study using the traditional method of teaching) and the creative thinking of experimental group (those who study using drama) according to the pre-creative thinking test because the pvalue is more than 0.05 .

\section{The third question:}

To answer the Second question " Is there any statistically significant difference between the achievement of control group (those who study using the traditional method of teaching) and the achievement of experimental group (those who study using drama) according to the post-creative thinking test?", data was treated by using the statistical program "SPSS". Data treatment reveals the mean and Std. Deviation of post-test of control and experimental groups as follows:

Table (5)

\begin{tabular}{|l|l|l|l|}
\hline Groups & N & Mean & Std. Deviation \\
\hline Control & 20 & 54.15 & 20.45 \\
\hline Experimental & 22 & 102.86 & 22.73 \\
\hline
\end{tabular}

Table (5) indicated that the mean of degrees of experimental group is more than the mean of degrees of control group.

To test the statistically significant difference between the creative thinking of control group (those who study using the traditional method of teaching) and the creative thinking of experimental group (those who study using drama) according to the post-creative thinking test, independent samples $\mathrm{T}$ test was usedas in the following table:

Table (6)

\begin{tabular}{|c|c|c|c|c|}
\hline Pre test & $\mathrm{T}$ & df & Mean Difference & $\begin{array}{r}\text { Sig. } \\
\text { p-value }\end{array}$ \\
\hline experimental $\times$ control & 7.27 & 40 & 48.71 & 0.00 \\
\hline
\end{tabular}

Table (6) indicated that there are statistically significant differences between the creative thinking of control group (those who study using the traditional method of teaching) and the creative thinking of experimental group (those who study using drama) according to the post-creative thinking test because the pvalue is less than 0.05 .

\section{Results' discussion:}

As shown by the results, there is a statistically significant difference in mean scores of the pre and post test of the experimental group. The mean of post grades of experimental group is more than the mean of pre grades ofexperimental group.It was indicated that there exist statistically significant differences instudents' pre and post grades of experimental group because of the p-value is less than 0.05. That means teaching English subject using drama is effective in the development of first year intermediate students' creative thinking. This is consistent with the results of Ortiz-Seda (1984), Dupre (2006) and Taskin (2013) studies.

On the other hand, data analysis revealed that there is no statistically significant difference in the mean grades of control and experimental groups according to the pre creative thinking test as the mean scores of experimental group was 54.40 and the mean scores of the mean scores of the experimental group was 52.36 (i.e.) there are no statistically significant differences between the creative thinking of control group (those who study using the traditional method of teaching) and the creative thinking of experimental group (those who study using drama) according to the pre-creative thinking test because the p-value is more than 0.05 . That means the two groups have the same level of creativity and ready to start the experiment. No previous differences will affect the experiment.

Results also revealed that there are statistically significant differences between the creative thinking of control group (those who study using the traditional method of teaching) and the creative thinking of experimental group (those who study using drama) according to the post-creative thinking test because the pvalue is less than 0.05 and this insure the effectiveness of teaching English using drama on the students creative thinking.Thus, results of the present study consistent with the study of Barreto (2014), Gomez (2010), Baraldi (2009), Uddin (2009),Ntelioglou (2006), Culham (2003) and Gaudart (1990). 


\section{Recommendation and suggestions:}

Based on the findings of the study, the following recommendations and suggestions are made:

1. Teachers should be trained on how to teach using drama in their classes.

2. Foreign language teaching should adopt dramatic activities to help students improve their personalities, achievement and cultural awareness of the foreign language.

3. The present Torrance test can be used in other research to investigate the influence of teaching subjects other than English using drama on students' creative thinking.

4. Further research is needed to investigate the influence of teaching English language using drama on teachers' performance.

5. Further research is needed to investigate the influence of teaching subjects other than English using drama on the development of students' achievement.

6. Further research is needed to investigate the influence of teaching subjects other than English using drama on the development of students' creative thinking.

\section{References}

[1]. Alesaoy, S.A. (2004) "The effect of dramatization of Arabic language on developing some topics of language and social skills among mentally retarded students". A research paper. Ain Shams University, Childhood High Studies Institute.

[2]. Baraldi, Sara. Margarita. (2009) "Drama and theater practices in the elementary classroom that create conductive environments for nonenglish speakers' English language acquisition". PHD Dissertation, Arizona state university. UMI Number: 3380660.

[3]. Barreto, E.A. (2014) "Educational drama and language acquisition for English proficiency". California State University, Los Angeles, ProQuest, UMI Dissertations Publishing 1554673.

[4]. Blanch, E. (1974) "Dramatics in the Foreign-Language Classroom. ERIC Focus Reports on the Teaching of Foreign Languages", No. 23. ERIC Clearinghouse on Languages and Linguistics, New York, NY.. MLA Publications Center; 62 Fifth Avenue, New York, N. Y. 10011

[5]. Burke, A. \& O'Sullivan, J. (2002). "Stage by Stage: A Handbook for Using Drama in the Second Language Classroom": PP. 192. Web site:http://www.heinemann.com.

[6]. Campbell, Margaret P. (2008). "The Infusion ofTheater Arts in the Teaching ofLanguage Arts:Its Impact on the Academic Achievement ofFifth Grade Students". PHE Dissertation, College ofEducation and Human Services, Seton Hall University. UMI Number: 3448171

[7]. Culham, Cameron. R. (2003). "Making the conversations possible: Drama as a methodology in developing the language of the everyday in ESL classrooms". University of Victoria.

[8]. Cunico, S. (2005). "Teaching Language and Intercultural Competence through Drama: Some Suggestions for a Neglected Resource". Language Learning Journal 31.1 (2005): 21-29. Routledge. ; 325 Chestnut Street Suite 800, Philadelphia, PA 1910

[9]. Cushman, Camille (2011). "Re-imagining Reading Instruction for English Language Learners: A Performance Ethnography of Collaborative Play, Inquiry and Drama with Shakespeare in a Third Grade Classroom". M.Ed.

[10]. Dunn, J. \& Stinson, M. (2011). "Not without the Art!!the Importance of Teacher Artistry When Applying Drama as Pedagogy for Additional Language Learning". Research in Drama Education 16.4: 617-633. Routledge. ; 325 Chestnut Street Suite 800, Philadelphia, PA 19106.

[11]. Dupre, Barbara Jeanne (2006). "Creative Drama, Playwriting, Tolerance, and Social Justice".PhD dissertation, Language, Literacy, and Sociocultural Studies, The University of New Mexico 2006. UMI Number: 3220936

[12]. Even, Susanne. "Moving in(to) Imaginary Worlds: Drama Pedagogy for Foreign Language Teaching and Learning". Susanne Even Indiana University. UP 41.2 (Fall 2008).

[13]. Gasparro, M.;Falletta, B. (1994) "Creating Drama with Poetry: Teaching English as a Second Language through Dramatization and Improvisation". ERIC Digest.ERIC Clearinghouse on Languages and Linguistics, Washington, DC. 4 ERIC/CLL, April 1994. 20037.

[14]. Gaudart, H. (1990) "Using Drama Techniques in Language Teaching". Available online, if indexed January 1993 onward.

[15]. Gomez, David Izquierdo (2010). "Using drama to improve oral skills in the ESL classroom". International Schools JournalVol XXX No.1 November 2010.

[16]. Holden, S. (1981). Drama in Language Teaching. Longman; , 19 West 44th Street, New York,

[17]. Kao,S-M.; Carkin.G.; Hsu.L-F. (2011) "Questioning Techniques for Promoting Language Learning with Students of Limited L2 Oral Proficiency in a Drama-Oriented Language Classroom". Research in Drama Education: 489-515. Routledge. ; 325 Chestnut Street Suite 800, Philadelphia, PA 19106

[18]. Kao, Shin-Mei, and Cecily O’Neill.(1998). Words Into Worlds: Learning a Second Language Through Process Drama. Stamford, CT: Ablex

[19]. Mattevi, Yvonne. (2005). "Using Drama in the classroom: the educational values of theatre in second language acquisition". PHD Dissertation, Stony Brook University. UMI number: 3189394

[20]. Ntelioglou, BurcuYaman. (2006). "Crossing borders: Drama in the second language classroom. ME Thesis. Graduate Program in Education". York University Toronto, Ontario. May 2006.

[21]. Ortiz-Seda, D. W. (1984)."The Use of Creative Dramatics in the Teaching of Drama with Special Application to the Teaching of English as a Second Language". 042 Dissertations/theses - Masters Theses, 141 Reports - Descriptive, 052 Guides - Classroom - Teacher.

[22]. Özdemir, Soner Mehmet and Çakmak, Aygen. "The effect of drama education on prospective teachers' creativity". International Journal of Instruction.

[23]. Shand, Jennifer Wood (2008). "The use of drama to reduce anxiety and increase confidence and motivation towards speaking English with two groups of English language learners". A Thesis Submitted to the Faculty of the school of theatre arts. MA thesis. Graduate College, university of Arizona.

[24]. Taskin-Can, B. (2013) "The Effects of Using Creative Drama in Science Education on Students' Achievements and Scientific Process Skills".IIkogretimOnline.Vol. 12 Issue 1, p120-131. 12p. article.

[25]. Taylor, Linda D. "Creative Thinking and Worldviews in Romania", PHD Dessirtation, 2008, UMI Number: 3311919 , University of Nevada, Ren

[26]. Uddin,Rukhsana. (2009)."Implementing Counseling Techniques: Role Play and Storytelling in Teaching Second Language Vocabulary to Adult Second Language Learners". PHD Dissertation. The University of Mississippi. UMI Number: 3358517 